$14^{\text {th }}$ Conf. Agric. Develop. Res., Fac. of Agric., Ain Shams Univ., March, 2019, Cairo, Egypt

Special Issue, 27(1), 367 - 374, 2019

Website: http://strategy-plan.asu.edu.eg/AUJASCI/

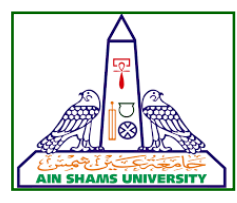

\title{
In vitro MATURATION OF DROMEDARY SHE-CAMEL OOCYTES EXPOSED TO LASER IRRADIATION
}

\section{Maiada, W.A. Allam ${ }^{1}$, Abdalla ${ }^{2}$ E.B., KhaliI ${ }^{2}$ F.A., Zeidan ${ }^{3}$ A.E.B., Abdel-Salam ${ }^{4}$ Z.A. and Badr ${ }^{5}$ M.R.}

1- Directorate of Veterinary Medicine, Cairo, Egypt

2- Animal Production Dept., Fac. of Agric., Ain Shams Univ., P.O. Box 68, Hadayek Shubra 11241,Cairo, Egypt

3- Animal Production Res. Inst., Dokki, Giza, Egypt

4- National Inst. Laser Enhanced Sci., Cairo Univ., Giza, Egypt

5- Artificial Insemination and Embryo Transfer Dept., Animal Reproduction Res. Inst., Agric. Research Center, Giza, Egypt

${ }^{*}$ Corresponding author: maiada_wagdy@yahoo.com

Received 24 October, 2018, Accepted 27 November, 2018

\section{ABSTRACT}

The objective of this study was to study the effect of laser irradiation on maturation rate of dromedary she-camel oocytes. Although in vitro fertilization (IVF) technique in she-camel has been established, but maturation rate of camel oocytes is still low comparing with other animal species. Several studies performed to improve in-vitro maturation rate using different types of media with different incubation times. In order to establish high sensitive and low cost maturation improvement technique, laser irradiation has been suggested in the present work.

Cumulus oocytes complexes (COC's) were collected from ovaries by aspiration method and grade $(A)$ oocytes were chosen and divided into five different groups, 62 oocytes served as control group, an un-irradiated (group 1), 64 oocytes exposed to 2 minutes of laser irradiation (group 2), 57 oocytes exposed to 3 minutes of laser irradiation (group 3), 49 oocytes exposed to 4 minutes of laser irradiation (group 4) and 52 oocytes exposed to 5 minutes of laser irradiation (group 5) with a total output power of $3 \mathrm{~mW}$ for different exposure durations; 2, 3, 4 and 5 minutes. Afterwards, oocytes were matured in TCM- 199 medium at $38.5^{\circ} \mathrm{C}$ and $5 \% \mathrm{CO}_{2}$ in humidified air for $42 \mathrm{~h}$. Maturation rate was calculated based on expulsion of the first polar body and statistically analyzed by one way ANOVA test.
The obtained results showed that, the oocytes reached germinal vesicles (GV) which exposed to laser beam for 5 minutes at $488 \mathrm{~nm}$ wavelength represent significantly $(\mathrm{P}<0.05)$ the highest value (42.31\%) compared to control (not irradiated, $16.13 \%$ ). However, other groups of GV showed insignificant differences with the control group. The metaphase II (M II) in the control oocytes represents significantly $(P<0.05)$ the highest value (75.81\%) compared to $3-5$ minutes exposed groups. The degenerated oocytes exposed to laser beam for 5 minutes at $488 \mathrm{~nm}$ wavelength represent significantly $(\mathrm{P}<0.05)$ the highest value $(40.38 \%)$ compared to control (not irradiated, $8.06 \%$ ). In conclusion, these results indicated that the exposure of laser irradiation for 2 minutes may improve in-vitro nuclear maturation of immature oocytes in dromedary she-camels as compared to other durations (3-5 minutes) at $488 \mathrm{~nm}$ wavelength (blue laser).

Keywords: She-camels, Oocytes, Laser irradiation, In-vitro maturation

\section{INTRODUCTION}

Oocytes maturation are known as the sequence of events that occur from the GV stage to complete of the division of the second meiotic by the formation of the second polar body $\left(2^{\text {nd }} P B\right)$. Nuclear maturation is characterized by the ability of the oocyte to resume meiotic division to the M II تحكيم: ا.د عبداله محمد عاشور

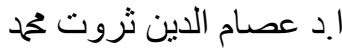


during IVM and the expulsion of the $2^{\text {nd }} P B$ (Blanco et al 2011). This is the reason for the vast majority of the oocytes matured in vitro that have been punctured from the antrum follicles early and thus are meiotically competent (Watson, 2007).

Laser technology is the latest addition to the list of assisted hatching $(\mathrm{AH})$ techniques. The laser $\mathrm{AH}$ (LAH) technique can be useful in the transferring embryos produced either in-vitro or in-vivo by increasing the rates of blastocyst hatching, that may increase the rates of implantation and pregnancy subsequently (Chiasson, 2010). Use of laser is the best method to deliver energy to cells; the laser energy is absorbed by cells and used in any function performed at irradiation time (i.e. mitosis, synthesis etc.), according to Almeida-Lopes et al (2001).

The application of LAH for assisted reproductive technologies (ART) has become widespread, a crucial and integral part to the IVF laboratory and ease of use, the LAH has made biopsy of polar body and embryo are common procedures (Taylor et al 2010). The use of the laser has added to improve and enhance the IVF field with use in other procedures like laser assisted intra-cytoplasmic sperm injection (ICSI) (Rienzi et al 2001 and Nagy et al 2001). In addition, laser assisted was immobilization of sperm prior to ICSI (Ebner et al 2001) and most recently, trophectoderm biopsy (Veiga et al 1997).

Therefore, the present study aimed to assess the effect of low-level laser irradiation (LLLI) blue laser light of wavelength $488 \mathrm{~nm}$ with a total output power $3 \mathrm{~mW}$ on oocytes of dromedary she-camel during in vitro maturation (IVM) for different duration intervals (2, 3, 4 and 5 minutes).

\section{MATERIALS AND METHODS}

The present study was conducted in the Embryo Transfer (ET) Lab., Artificial Insemination (Al) and Embryo Transfer (ET) Department, Animal Reproduction Research Institute (ARRI), Haram, Giza, Egypt, in cooperation with the Laser Atomic Spectroscopy Lab., National Institute of Laser Enhanced Sciences (NILES), Cairo University, Giza, Egypt. The Experimental work was carried out during the period from November, 2016 to April, 2017, at a local Automated El-Bassatein Abattoir, Cairo.

The present study aimed to define the impact of exposure dromedary she-camel oocytes to blue light laser irradiation level of wavelength $488 \mathrm{~nm}$ continuous wave (CW) on in-vitro maturation (IVM) during breeding season. Oocytes were categorized at nuclear maturation as germinal vesicles (GV), metaphase II (M II) and degenerated oocytes (DO).

\subsection{Ovaries collection}

A total number of 134 ovaries collected from 67 clinically healthy she-camel was used in this study. Ovaries were collected from the dromedary shecamel and immediately after slaughtering, ovaries were transported to the laboratory placed into thermoflask in physiological saline solution $(0.9 \%$, $\mathrm{w} / \mathrm{v}, \mathrm{NaCl}$ ) supplemented with antibiotics (100 $\mathrm{IU} / \mathrm{ml}$ penicillin, $100 \mu \mathrm{g} / \mathrm{ml}$ streptomycin and $2.5 \mu \mathrm{g} / \mathrm{ml}$ amphotericin) maintained at $30-37^{\circ} \mathrm{C}$, within 1 to $2 \mathrm{~h}$ after slaughtering.

In the laboratory, the excessive tissues were excised from the ovarian stalk and the ovaries were washed three times with warmed $\left(30^{\circ} \mathrm{C}\right)$ phosphate buffered saline (PBS) supplemented with antibiotics (100 IU penicillin and $100 \mu \mathrm{g}$ streptomycin $/ \mathrm{ml}$ ) to remove adhering tissues and clotted blood. Then all ovaries were quickly washed one time with ethanol $(70 \%)$ to remove any contamination on the ovarian surface.

\subsection{Oocyte collection}

Before commencing aspiration, the needle and syringe are first primed with approximately $0.25 \mathrm{ml}$ of aspiration medium. Oocytes were aspirated from all visible follicles $(2-8 \mathrm{~mm})$ in diameter using a 20 gauge hypodermic needle attached with a sterile disposable $(5 \mathrm{ml})$ syringe containing $(2 \mathrm{ml})$ aspiration medium (Phosphate buffered saline, PBS). After aspiration, contents of syringe were placed into a disposable Petri dish $(3.5 \times 1.0 \mathrm{~cm})$ containing $3 \mathrm{ml}$ of PBS for examined oocytes under stereomicroscopy.

\subsection{Oocyte categories}

After collection, oocytes were washed three times in harvesting medium, counted, evaluated under inverted microscope and classified into five categories based on their cumulus investment and evenly granulated dark ooplasm as the method described by Madison et al (1992) as follows:

(1) Good Quality, compact cumulus oocytes complex (GQO)

Oocystes with $\geq 5$ layers of complete cumulus cells (CC) and evenly granulated dark ooplasm. 
(2) Fair Quality, cumulus oocytes complex (FQO)

Oocystes with 1-4 layers of complete CC and homogenous ooplasm.

(3) Partially denuded cumulus oocytes (PDCO)

Oocytes with incomplete surrounding CC.

(4) Denuded cumulus oocytes (DCO)

Oocytes without CC and covered only by zona pellucida (ZP).

\section{(5) Degenerated oocytes (DO)}

Oocytes with ooplasm shrunken away from ZP or not evenly filling the zona.

Generally good and fair oocytes (GQO and FQO) were considered as indicators of maturation of the oocytes.

\subsection{Irradiation and Maturation of Immature Oo- cytes}

Blue laser $(\lambda=488 \mathrm{~nm})$ from a Diode Pumped Solid State (DPSS) laser [LSR-PS-II] with a total output power of $3 \mathrm{~mW}$ has been used for irradiation of the oocytes before maturation. For stability, the laser was turned on 10 minutes before starting the exposure. Cumulus oocytes complexes were chosen and divided into five different groups, 62 oocytes served as control group, an un-irradiated (group 1), 64 oocytes exposed to 2 minutes of laser irradiation (group 2), 57 oocytes exposed to 3 minutes of laser irradiation (group 3), 49 oocytes exposed to 4 minutes of laser irradiation (group 4) and 52 oocytes exposed to 5 minutes of laser irradiation (group 5) with a total output power of $3 \mathrm{~mW}$ for different exposure durations; 2, 3, 4 and 5 minutes. Afterwards, oocytes were matured in TCM-199 medium at $38.5^{\circ} \mathrm{C}$ and $5 \% \mathrm{CO}_{2}$ in humidified air for $42 \mathrm{~h}$.

Irradiation was carried out in a safety cabinet at room temperature. During irradiation treatments, all Eppendorf tubes containing COC's within an experiment (excluding controls) were maintained in basic maturation medium at room temperature for the same length of duration (up to $5 \mathrm{~min}$ ). After the incubation period, the COC's were fixed and examined for assessment of oocyte maturation under inverted microscope by high magnification. After fixation and staining, first polar body (PB) and metaphase II (M II) were indicators for oocyte maturation.

\subsection{Laser Specifications and Irradiation Pa- rameters}

The physical parameters of Argon ion blue light laser used (Medical Investigation Laser System, Model TM 1083) listed in Table (1) in this study were as follows: wavelength $488 \mathrm{~nm}$; average power output was $3 \mathrm{~mW}$. The irradiance of 3 $\mathrm{mW} / \mathrm{cm}^{2}$ was calculated using the following equation:

$$
\text { Irradiance }=\frac{\text { Power output }(\mathbf{m W})}{\text { Application surface }\left(\mathrm{cm}^{2}\right)}
$$

Table 1. Laser specification and irradiation parameters

\begin{tabular}{|c|c|}
\hline Laser & Argon ion \\
Operation mode & CW (continuous wave) \\
Wavelength (nm \& color) & 488 (blue) \\
Photon energy (eV) & 2.85 \\
Power output (mW) & 3 \\
Application & Irradiation \\
\hline
\end{tabular}

\subsection{Statistical analysis}

Data were statistically analyzed by one way ANOVA, using General Linear Model (GLM) procedure of SAS (Goodnight et al 1986) and Duncan's Multiple Range Test (Duncan, 1955) was used to detect significant differences among means. Percentage values were transformed to arc-sin values before being statistically analyzed. The following statistical model used in the experiment as follows:

Where,

$$
Y_{\mathrm{ij}}=\mu+L_{\mathrm{i}}+e_{\mathrm{j}}
$$

Yij = observation of oocyte maturation parameters (a study case)

$\mu=$ overall mean

$\mathbf{L}_{\mathbf{i}}=$ effect of the laser irradiation durations

eij $=$ random error

\section{RESULTS AND DISCUSSION}

Effect of blue light laser level at $488 \mathrm{~nm}$ wavelength on

\subsection{In-vitro maturation (IVM) parameters}

The effects of laser irradiation level on the invitro maturation (IVM) of the dromedary she-camel 
oocytes at $488 \mathrm{~nm}$ wavelength during breeding season (December-April) are presented in Table (2).

\subsubsection{Germinal vesicles (GV)}

The oocytes reached germinal vesicles (GV) of the dromedary she-camels during breeding season (Table 2) were significantly $(P<0.05)$ higher when exposed to laser beam for 5 minutes at $448 \mathrm{~nm}$ wavelength than the control. The highest $(P<0.05)$ value of the GV was recorded with the oocytes exposed to laser beam for 5 minutes (42.31\%), while the lowest $(\mathrm{P}<0.05)$ value was recorded in control (16.13\%). These results are in agreement with those reported by Moreno Millan and Ocaña Quero (2009), who used low power of He-Ne laser to treat immature oocyte and found that laser beam with doses of 0.4 and $2 \mathrm{~J} / \mathrm{cm}^{2}$ affected the maturation rate negatively and caused nuclear damage. Ocaña Quero et al (1995) reported that the use of He-Ne laser beam at 0.4 and $2 \mathrm{~J} / \mathrm{cm}^{2}$ has a detrimental effect on IVM process of immature bovine oocytes.

\subsubsection{Metaphase II (M II)}

The oocytes reached metaphase II (M II) of the dromedary she-camels during breeding season (Table 2) were significantly $(P<0.05)$ higher in control than those exposed to laser beam for 3, 4 and 5 minutes at $448 \mathrm{~nm}$ wavelength. The highest $(P<0.05)$ value of the oocytes reached $M$ II was recorded in control (75.81\%), while the lowest $(\mathrm{P}<0.05)$ value of the oocytes reached $\mathrm{M}$ II was significantly recorded when oocytes were exposed to laser beam for 5 minutes $(17.31 \%)$. While exposure of oocytes for 2 minutes was not significantly different with control. These results are in agreement with those obtained by Ocaña Quero et al (1995), who reported that maturation rates obtained in the control group (85\%) were significantly $(\mathrm{P}<0.001)$ higher than those obtained in the group of oocytes irradiated at $2 \mathrm{~J} / \mathrm{cm}^{2}(63 \%)$. while the oocyte group exposed to an irradiation dose of 0.4 $\mathrm{J} / \mathrm{cm}^{2}$ obtained a maturation rate slightly lower $(72 \%)$ than that of control group.

These results are in disagreement with those reported by Moreno Millan and Ocaña Quero (2009), the He-Ne laser irradiation (632 nm) was used in IVF to treat immature oocytes; the use of laser irradiation at doses of 0.4 and $2 \mathrm{~J} / \mathrm{cm}^{2}$ produced a negative effect in the process of maturation, with significant damage at the level of nucleus and cytoplasm. Also, El-Sayed et al (2013) mentioned that the buffalo oocytes irradiation with green laser light $(532 \mathrm{~nm})$ to laser beam for $8 \mathrm{~min}$ represents significantly $(P<0.05)$ the highest value of maturation rate $(59.3 \%)$ in comparison with the control $(33.4 \%)$, while other groups of maturation rate showed insignificant differences. Maturation rate indicated an increasing pattern with duration of laser irradiation exposure starting from 2 min to $8 \mathrm{~min}$ and reduced at $10 \mathrm{~min}$ (El-Sayed et al 2013).

Oocytes reached M II stage indicating that oocytes approached maturity and prolonged exposure to laser irradiation decreased maturation rate. The species of animal, wavelength of laser light and duration of laser exposure may be important factors affecting maturation rate of oocytes.

\subsubsection{Degenerated oocytes (DO)}

The oocytes showed degenerated stage of the dromedary she-camels (Table 2) were significantly $(P<0.05)$ higher when exposed to laser beam for 5 minutes at $448 \mathrm{~nm}$ wavelength than for 2, 3 and 4 minutes exposure and the control. The highest $(P<0.05)$ value of the degenerated oocytes (DO) was recorded at exposure to laser beam for 5 minutes $(40.38 \%)$, while the lowest $(P<0.05)$ value of the DO was recorded at control (8.06\%).

These results are in agreement with those reported by Ocaña Quero et al (1995), who found that the laser-exposed oocytes showed degenerative changes on both cytoplasm and chromosomes as compared to unexposed oocytes to laser beam that showed a homogeneous cytoplasm and disperse chromosomes. Moreno Millan and Ocaña Quero (2009) found that $\mathrm{He}-\mathrm{Ne}$ laser with doses of 0.4 and $2 \mathrm{~J} / \mathrm{cm}^{2}$ affected negatively on the maturation rate and caused nuclear damage.

Short irradiation exposure period can be very useful in IVM technique to avert contamination and any undesired effects because of long irradiation exposure of oocytes in the surrounding condition. Nevertheless, studies showed that the cellular photoreceptors are capable of absorbed photon energy which may stimulate chemical reactions at specific wavelengths (Abdel-Salam \& Harith, 2015). 
Table 2. Effect of blue light laser irradiation on in-vitro maturation (IVM) parameters in the dromedary she-camel oocytes at wavelength $488 \mathrm{~nm}$ (Means $\pm \mathrm{SE}$ )

\begin{tabular}{|c|c|c|c|c|}
\hline \multirow{2}{*}{$\begin{array}{c}\text { Durations of laser } \\
\text { irradiation } \\
\text { (Minutes) }\end{array}$} & No. of oocytes & GV \% & M II \% & DO \% \\
\cline { 3 - 5 } & 62 & $16.13^{\mathbf{b}} \pm 0.67$ & $75.81^{\mathbf{a}} \pm 0.67$ & $8.06^{\mathbf{b}} \pm 0.67$ \\
\hline Control & 64 & $20.31^{\mathbf{a b}} \pm 1.33$ & $64.06^{\mathbf{a}} \pm 1.67$ & $15.62^{\mathbf{b}} \pm 2.85$ \\
\hline $\mathbf{2}$ & 57 & $31.57^{\mathbf{a b}} \pm 1.15$ & $42.10^{\mathbf{b}} \pm 0.57$ & $26.31^{\mathbf{a b}} \pm 0.57$ \\
\hline $\mathbf{3}$ & 49 & $28.57^{\mathbf{a b}} \pm 0.67$ & $30.61^{\mathbf{b c}} \pm 1.15$ & $40.82^{\mathbf{a}} \pm 1.33$ \\
\hline $\mathbf{4}$ & 52 & $42.31^{\mathbf{a}} \pm 1.20$ & $17.31^{\mathbf{c}} \pm 0.57$ & $40.38^{\mathbf{a}} \pm 1.53$ \\
\hline $\mathbf{5}$ & 52 &
\end{tabular}

GV = Germinal vesicle, $\mathbf{M} \mathbf{~ I I}=$ Metaphase II and $\mathbf{D O}=$ Degenerated oocytes

Table represents mean number of oocytes (\%) in each stage of maturation.

${ }^{a-c}$ Values in the same column with different superscripts differ significantly $(P<0.05)$

\section{CONCLUSIONS}

In conclusion, irradiating immature she-camel oocytes with blue laser light $(488 \mathrm{~nm})$, continuous wave at $2.85 \mathrm{eV}$ photon energy is may appropriately used for in-vitro nuclear maturation rate within 2 minutes than other durations of irradiation $(3,4$ \&

$5)$ minutes. The obtained improvement in oocytes maturation due to the shorter wavelength $(\lambda=488$ $\mathrm{nm})$ used (blue laser light) where the photon energy is higher $(2.85 \mathrm{eV})$ is promising and more reasonable for biological purposes because they will be absorbed by the cellular photoreceptor.

Present study recommend to indicate that the exposure of laser irradiation for 2 minutes at 488 $\mathrm{nm}$ wavelength may increase or improve in-vitro nuclear maturation of immature oocytes in dromedary she-camels, while laser irradiation induced high percentage of germinal vesicles and degenerated oocytes at 4 and 5 minutes. Furthermore, it is recommended that more studies should be done to assess the effect of laser irradiation technique using other different wavelengths like green laser light $(532 \mathrm{~nm})$ or red laser light $(632 \mathrm{~nm})$ with different durations of exposure for dromedary shecamel oocytes maturation.

\section{REFERENCES}

Abdel-Salam Z. and Harith M.A. 2015. Laser researches on livestock semen and oocytes: $A$ brief review. J. Adv. Res., 6(3), 311-317.

Almeida-Lopes L., Rigau J., Amaro Zângaro R., Guidugli-Neto J. and Jaeger M.M. 2001. Comparison of the low level laser therapy effects on cultured human gingival fibroblasts proliferation using different irradiance and same fluence. Lasers in Surgery and Medicine, 29(2), 179-184.

Blanco M.R., Demyda S., Moreno Millan M. and Genero E. 2011. Developmental competence of in vivo and in vitro matured oocytes: A Review Biotech. Mol. Biol. Reviews, 6(7), 155-165.

Chiasson M.K. 2010. Laser-assisted zona pellucida hatching of frozen-thawed in vivoproduced bovine embryos. M.Sc. Thesis, Fac. of Agric. and Mechanical, Louisiana State Univ., USA, pp. 1-119.

Duncan D.B. 1955. Multiple range and multiple Ftest. Biometrics, 11, 1-42.

Ebner T., Yaman C., Moser M., Sommergruber M., Hartl J. and Tews G. 2001. Laser assisted immobilization of spermatozoa prior to intracytoplasmic sperm injection in humans. Hum. Reprod., 16(12), 2628-2631.

El-Sayed A., Abdel-Salam Z., Gad A., Harith M.A. and Khalifa M. 2013. Effect of laser irradiation on in vitro maturation rate and gene expression of buffalo oocytes. In Conference: $29^{\text {th }} \quad$ Annual Meeting Association Européenne de Tranfert Embryonnaire, Istanbul, Turkey, 29(9), 126.

Goodnight J.H., Sail J.P. and Sarle R.F. 1986. The GLM procedure. In: A.A. Ray (Editor), SAS User's Guide. Statistics. SAS Institute Inc., NC, USA, pp. 99-139.

Madison V., Avery B. and Greve T. 1992. Selection of immature bovine oocytes for developmental potential in vitro. Animal Reprod. Sci., 27(1), 1-11.

Moreno Millán M. and Ocaña Quero J.M. 2009. Preliminary Results of the Evaluation of the Use of Clinical Laser He-Ne Radiation in the 
Process of Bovine "in Vitro Fertilization." Bulletin Univ. Agric. Sci, Vet. Med. ClujNapoca, Romania, Vet. Med., 66(1), 495.

Nagy Z.P., Oliveira, S.A., Abdelmassih V. and Abdelmassih R. 2001. Novel use of laser to assist ICSI for patients with fragile oocytes: a case report. Reprod. BioMed. Online, 4(1), 27-31.

Ocaña Quero J.M., Gomez Villamandos R.J., Moreno Millán $\mathbf{M}$. and Santisteban Valenzuela J.M. 1995. The effect of heliumneon laser irradiation on in vitro maturation and fertilization of immature bovine oocytes. Lasers in Medical Sci., 10(2), 113-119.

Rienzi L., Greco E., Ubaldi F., lacobelli M., Martinez F. and Tesarik J. 2001. Laserassisted intracytoplasmic sperm injection. Fertility and Sterility, 76(5), 1045-1047.
Taylor T.H., Gilchrist J.W., Hallowell S.V., Hanshew K.K., Orris J.J., Glassner M.J. and Wininger J.D. 2010. The effects of different laser pulse lengths on the embryo biopsy procedure and embryo development to the blastocyst stage. J. Assist. Reprod. Genet., 27(11), 663-667.

Veiga A., Sandalinas M., Benkhalifa M., Boada M., Carrera M., Santaló J., Barri P.N. and Ménézo Y. 1997. Laser blastocyst biopsy for preimplantation diagnosis in the human. Zygote, 5(4), 351-354.

Watson A.J. 2007. Oocyte cytoplasmic maturation: a key mediator of oocyte and embryo developmental competence. J. Animal Sci., 85(13 Suppl), 1-3. 
المؤتمر الرابع عشر لبحوث التننمية الزراعية،

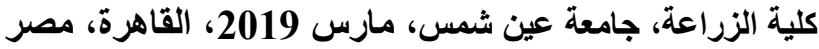

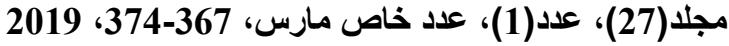

Website: http://strategy-plan.asu.edu.eg/AUJASCl/

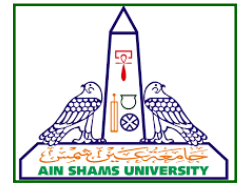

إنضاج معملى لبويضات النوق العربية عرضت للتثعيع باللثيز

[34]

ميادة وجدى أحمد علام²- عصدت بكرى عبدالله²- فاروق عبدالله خليل2 - علاء السيد بلاسى زيدان 3- زينب عبدالفتاح عبدالسلام4 - مجدى ريدان

$$
\begin{aligned}
& \text { 1- مديرية الطب البيطري - القاهرة - مصر } \\
& \text { 2- قسم الإنتاج الحيوانى - كلية الزراعة- جامعة عين شمس - ص.ب 68- } 11241 \text { حدائق شبرا - القاهرة - مصر } \\
& \text { 3- معهد بحوث الإنتاج الحيوانى - الدقى - جيزة- مصر الإنى }
\end{aligned}
$$

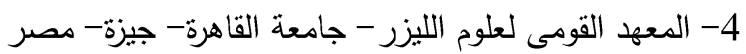

$$
\begin{aligned}
& \text { 5- قسم التلقيح الإصطناعى ونقل الأجنة- معهد بحوث التتاسليات الحيوانية- مركز البحوث الزراعية- - جيزة- مصر }
\end{aligned}
$$

*Corresponding author: maiada wagdy@yahoo.com

Received 24 October, 2018, Accepted 27 November, 2018

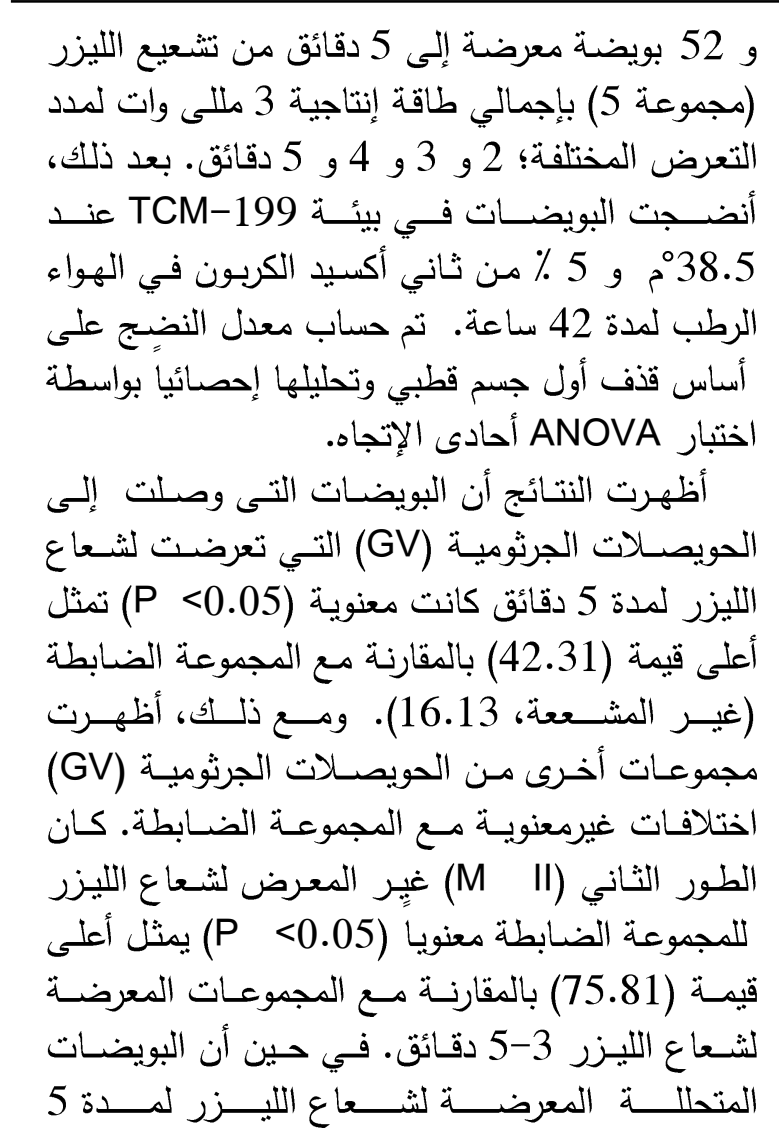

الهدف العام من هذه الدراسة هو إختبار معدل إنضاج

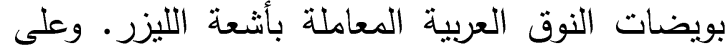

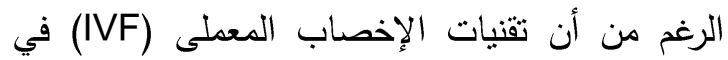
النوق العربية قد انثأت، إلإن أن الن معدل إنضاج البويضات في النوق العربية لا يزال منخفضا مقارنة الان التان

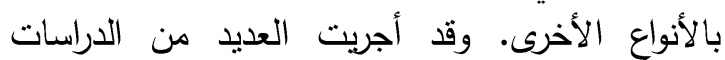
لتحسين معدل الإنضاج باستخدام أنواع مختلفة من الأن الوسائط مع فترات تحضين مختلفة. لتطوير تقات تقنية الإنضاج ليصبح أكثر حساسية وأقل تكلفة، تم إقتراح أثعة الليزر في العمل الحالي.

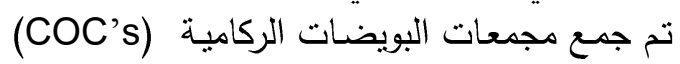

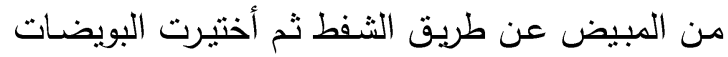

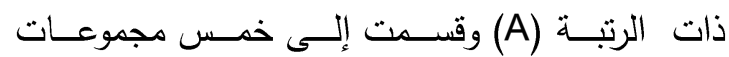

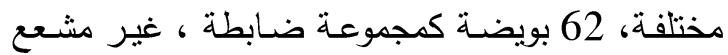

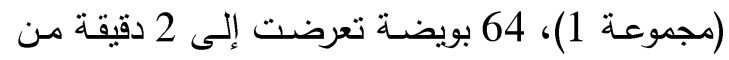

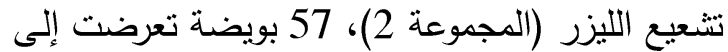

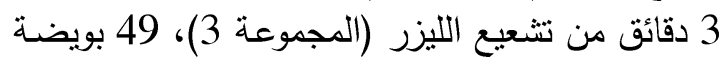

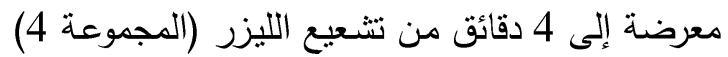




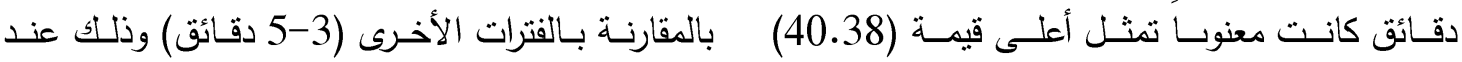

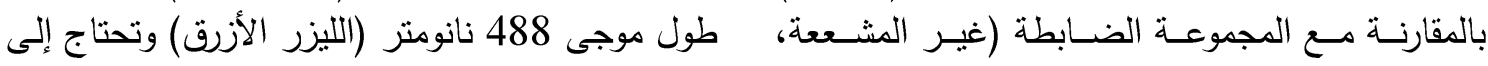

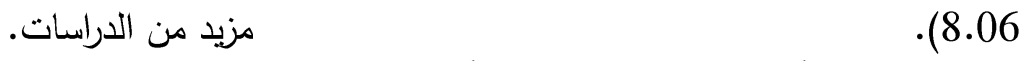

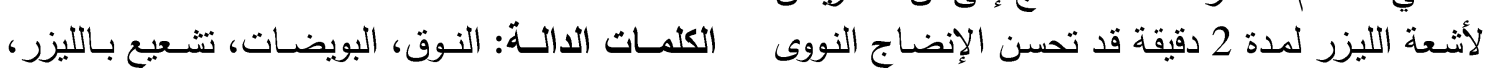

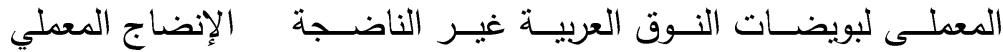

